\title{
鼣 \\ MEMAHAMI AGAMA \\ DENGAN PENDEKATAN ESOTERIK
}

\author{
M. Ikbal \\ IAIN Raden Intan Lampung \\ iqbal.m@gmail.com
}

\begin{abstract}
Abstrak
Artikel ini memperkenalkan aspek esoterik dalam memandang dan memahami hakekat agama. Pendekatan ini penulis tawarkan mengingat kekeliruan persepsi terhadap agama umumnya disebabkan karena agama hanya dilihat dari aspek eksoteris saja. Akibatnya, orang cenderung menghakimi dengan mengatakan bahwa suatu agama tertentu adalah benar dan yang lainnya adalah salah. Kecenderungan semacam ini pada gilirannya akan memunculkan sikap eksklusif di kalangan penganut agama dan tidak jarang pada akhirnya memicu konflik antar umat beragama.
\end{abstract}

Abstract

There is a common misperception toward religion as it is seen and understood from its exoteric aspect only. As a consequence, people tend to be judgmental by saying that particular religion is true and the other religions are false. It also might cause en axlusive attitude for its followers. In response to this phenomena, this article introduced a clear esoteric perspective in preceiving and understanding the essence of religion.

Kata Kunci: Agama, esoterik, eksoterik, absolut, relatif.

\section{A. Pendahuluan}

Terlalu memalukan untuk disebut satu-persatu dalam berbagai persengketaan, peperangan, saling bunuh, dan sebagainya, telah menodai kesucian agama. Oleh sebab itu, berpijak dari fakta 
historis demikian, ada rasa apatis sementara kalangan, terutama yang anti agama, jika agama ditempatkan sebagai juru damai atau juru selamat bagi umat manusia. Menurut mereka, kehadiran agama hanya akan mempersukar dan menghitamkan lembaran-lembaran sejarah kehidupan, yang selanjutnya akan bermuara pada porakporanda dan bahkan kehancuran kemanusiaan. Fakta demikian memang bisa dijadikan alasan untuk menuding agama sebagai biang kebangkrutan kemanusiaan. Akan tetapi, akan lebih sukar dan merupakan sesuatu hal yang absurd, jika agama dipinggirkan atau dihapuskan sama sekali. Ketika ilmu pengetahuan mulai mendapat tempat dalam kehidupan manusia pada sekitar abad 17, besar harapan umat manusia-terutama di Eropa pada waktu itu untuk menggusur agama dari kehidupan.

Dengan demikian, diharapkan kedudukan ilmu pengetahuan akan dapat mengganti kedudukan Tuhan (baca: agama) sebagai juru damai atau juru selamat bagi kehidupan insan. Akan tetapi, harapan demikian alih-alih akan menggusur agama, justru mendatangkan yang sebaliknya, bersamaan dengan kepesatan perkembangan ilmu pengetahuan agama pun hidup semakin subur. Tepat sekali apa yang dikatakan oleh Will Durant, sejarawan Amerika, bahwa agama memiliki seratus jiwa, karena itu tidak dapat dihapuskan dari muka bumi, satu kali ia dibunuh akan muncul lebih banyak lagi. ${ }^{1}$

Sebenamya agama tidak perlu dihapus. Menghapus agama sama dengan mencopoti jantung manusia dari jasadnya. Agama adalah fondasi kehidupan manusia yang paling fundamental. Al-Qur'an mensinyalir bahwa sebelum kelahiran telah terjadi perjanjian primordial antara Tuhan dan manusia: "Bukankah Aku Tuhanmu? Mereka menjawab, Ya. kami semua bersaksi." (QS. alA'raf [77]:172). Dari itu, dipercayai oleh para pemeluk agama bahwa menghapus agama dari muka bumi adalah sesuatu yang mustahil. Solusi terhadap kekerasan dan kebrutalan yang timbul pada pemeluk agama sebaiknya bukan dengan cara menghapus agama, tetapi dengan menyelami akar ajaran agama itu secara

${ }^{1}$ Ucapan ini dikutip oleh Murtadha Muthahhari dalam karyanya, Perspektif al-Qur'an tentang Manusia dan Agama, terj. Indonesia oleh Tim Penerjemah Mizan, (Bandung: Penerbit Mizan, 1419/1998), h. 41. 
fundamental. Sebab, tidak mungkin agama yang ilahiah dan suci itu mendorong manusia saling berbunuhan. Selama ini agama hanya dipahami secara sempit dan lebih terarah kepada penampilan lahiriah (eksoterik) yang beragam sementara substansi agama (esoterik) secara fundamental tidak dilihat secara mendalam. Akibatnya, terjadi keekslusifan dalam beragama dan memandang agama lain sebagai salah atau sesat. Keadaan demikian tentu akan memunculkan ketakharmonisan.

Bertolak dari pengalaman historis dan pandangan teologis yang sempit dan tertutup dalam sekat-sekat eksoterik itu, agaknya, kita harus melihat ke depan, dalam suasana global dan plural, sikap mau menang sendiri dan mau menikmati surga sendiri tidak dapat dipertahankan lagi, justru kita harus memiliki wawasan teologi yang luas dan transparan. Tulisan ini berupaya membuka sekatsekat lahiriah keagamaan untuk lebih jauh melihat kepada inti, sehingga akan didapatkan suatu ruang temu antar agama-agama yang ada. Lalu, dari situ kita akan dapat mengembangkan keberagamaan yang membawa kedamaian.

\section{B. Keniscayaan Perbedaan Agama}

Usia agama hampir sama tuanya dengan usia manusia. Sejak awal kehidupan manusia di muka bumi ini secara inheren telah beradaptasi dengan semacam kepercayaan atau keyakinan akan adanya yang gaib, yang memiliki superioritas atas segala yang ada, yang disebut Tuhan, Dewa, Hiyang, God, Ilah, dan berbagai sebutan lain dalam berbagai bahasa. Kepercayaan itu sedemikian melekat pada manusia, sehingga tidak dapat dipisahkan dari diri manusia. Atau, ia merupakan tabiat asasi manusia yang tidak mungkin dapat dicabut dari diri manusia. Kepercayaan demikian tentu saja mengandung konsekuensi bahwa manusia harus tunduk dan patuh kepada Yang Gaib dan Superior itu. Lalu, dari kepercayaan kepada Yang Gaib itu pula muncul keyakinan akan adanya normanorma dan nilai-nilai yang bersumber dari-Nya, yang lazim kita sebut agama.

Pada prinsipnya, agama adalah petunjuk Tuhan yang bertujuan membawa keselamatan dan kedamaian bagi manusia sejagat. Agama mengandung norma-norma dan nilai-nilai yang dapat menampung kepentingan manusia yang berbeda-beda, 
sehingga tercipta suatu kehidupan yang damai dan tenteram di muka bumi. Lebih dari itu, ajaran agama merupakan formula untuk menyembuhkan kekisruhan ruhani manusia, sehingga dapat memberikan kesejukan dalam kehidupan. Oleh sebab itu, tidak ada satu agama pun yang mengajarkan sesuatu yang buruk atau membawa keburukan bagi kehidupan insan. Segenap norma dan nilai dalam ajaran-ajaran agama-agama senantiasa mengarahkan manusia kepada kedamaian dan kesejukan ruhani.

Akan tetapi, dalam realitas sejarah agama-agama, kehidupan keberagamaan kelihatan tidak hanya memberikan dampak positif, sebagaimana tujuan asasi diturunkannya agama-agama itu, namun tidak sedikit pula menimbulkan ekses-ekses negatif, yang justru menghapus kedamaian dan ketenteraman. Ketika agama menyejarah dalam kehidupan sosial, temyata kehidupan keberagamaan para pemeluknya tidak lagi seperti tujuan asasi diturunkannya agama-agama itu, tetapi justru mengalami deviasi dan simbiose, sehingga sering dituding sebagai biang perpecahan, kebrutalan, dan berbagai ekses negatif yang lain.

Tentu segenap pemeluk agama tidak merasa senang kalau agama dikatakan sebagai pepicu berbagai peristiwa yang mengancam kehidupan sosial. Atau, agama dikatakan sebagai biang persengketaan antar pemeluk suatu agama dengan pemeluk agama lain. Akan tetapi, kenyataan membuktikan betapa banyak peristiwa burukyangyang muncul akibat kehidupan keberagamaan. Belumkah cukup bukti bahwa sepeninggal para rasul Tuhan dan para avatara bentrokan antar para murid dan para sahabat segera menyusul sesudahnya? Lalu, rentetan panjang peperangan antar ataupun intern umat beragama tercatat demikian rapi dalam lembaran-lembaran sejarah. Seakan-akan di balik janji-janji indah surgawi yang termaktub dalam kitab-kitab suci tersimpan virus berbahaya yang merusak tatanan kehidupan kemanusiaan.

Kita perlu ingat bahwa agama secara ontologis bersumber dari Tuhan, namun agama bukan untuk Tuhan; agama adalah untuk manusia. Oleh sebab itu, sesuatu agama yang bersifat transendental, ilahiah, dan sakral, ketika memasuki ruang terbatas, di mana ia bersentuhan dengan manusia yang memiliki sifatsifat terbatas dan profan. tidak bisa terhindar dari berbagai hal yang bersifat terbatas pula. Jadi, ketika agama menyejarah dalam 
kehidupan manusia, ia, di samping sifatnya yang transenden juga sekaligus imanen. Meminjam istilah Seyyed Hossein Nasr, agama itu merupakan sesuatu yang "relatively-absolute". ${ }^{2}$ Bentuk agama adalah relatif, namun di dalamnya terkandung muatan substansial yang mutlak. Karena itu, agama merupakan gabungan antara "substansi" dan "bentuk". Pada level substansi, kita temukan kebenaran mutlak yang dikandung oleh agama. Akan tetapi, ketika agama berinteraksi dengan kehidupan sosial manusia dengan berbagai keterbatasannya, maka di sini kebenaran mutlak dan tunggal yang bebas ruang-waktu diturunkan ke dalam dunia terbatas, maka ia pun mulai mengambil bentuk yang relatif, sesuai dengan keterbatasan dan vested interest (berbagai macam kepentingan individual) pemahaman para penafsimya.

Pada level agama sebagai kebenaran absolut, tidak ada perbedaan pandangan siapa pun dalam melihatnya sebagai rahmat bagi alam semesta (rahmatli-al-'dlamin), karena segenap ajaran agama yang bersifat universal senantiasa sejalan dengan fitrah manusia. Oleh sebab itu, siapa pun pasti akan mengakui keadilan, kasih sayang, kesantunan, dsb. sebagai suatu kebenaran transendental. Akan tetapi, ketika ajaran-ajaran itu diterapkan oleh manusia, dengan segala keterbatasannya, maka ajaran-ajaran agama yang universal itu akan terpecah-pecah dalam bentuk-bentuk yang partikular, dan masing-masing orang akan merasa benar sendiri dalam merealisasikan pemahamannya terhadap ajaran yang universal itu. Ketika itulah munculnya klaim bahwa sayalah yang benar, Anda salah; sayalah yang akan menjadi penghuni surga, Anda penghuni neraka; seakan-akan kebenaran dan surga itu adalah milik segelintir manusia dan manusia lain tidak berhak atasnya.

Sebenamya tidak seorang pun mau salah dan tersesat dalam hidupnya, semua orang ingin meraih keselamatan dan damai, dan masing-masing agama menjanjikan itu. Lalu, karena masing-masing agama itu menjanjikan hal demikian, muncul pertanyaan, apakah semua pemeluk agama itu akan mencapai tujuan tersebut? Atau, satu saja di antara yang banyak itu yang mencapai keselamatan dan kedamaian?

${ }^{2}$ Istilah ini dipakai oleh Seyyed Hossein Nasr dalam artikelnya yang berjudul The One in the Many, dipresentasikan pada parliament of the Word's Religions, Chicago, 2 September 1993. 
Sesungguhnya keselamatan dan kedamaian yang hakiki merupakan bagian dari, atau merupakan manifestasi kebenaran. Oleh sebab itu, ketika kebenaran dapat terealisasi dalam dunia kita, maka di situ keselamatan dan kedamaian itu akan dapat diraih. Akan tetapi, di sinilah akar permasalahannya selama ini. Masingmasing pemeluk gama mengklaim kebenaran di pihaknya. Klaim demikian, agaknya, berakar dari pendekatan teologis yang ekslusif, yang memandang kebenaran itu sebagai "milik saya" dan semua orang yang berada di "luar lingkungan saya" adalah salah, keliru, dan bahkan sesat.

Pendekatan teologis yang ekslusif itu telah membuat sekatsekat dan jarak antar komunitas-komunitas agama; masing-masing pemeluk agama merasa bahwa agamanyalah yang paling benar. Pandangan demikian, sebenarnya tidak dapat terlalu disalahkan, karena masing-masing pemeluk agama memang diarahkan dan diajar untuk bisa menjadi pengawal agamanya, dan bahkan dalam level tertentu bisa mengorbankan nyawanya demi agama. Dikatakan "tidak dapat terlalu disalahkan" karena mengingat kondisi sosial pada waktu tertentu memerlukan keperwiraan para pemeluk agama. Sebab, kalau tidak, niscaya agama yang mereka peluk bisa tergusur oleh agama lain, kendati kebenaran yang dikandung oleh agama itu sebenarnya telah dijamin oleh Tuhan kelanggengannya. Akan tetapi, para pemeluk agama bisa saja merasa khawatir, karena dalam kenyataan sejarah terjadi sekian banyak konflik antar umat beragama yang berujung pada penggusuran umat suatu agama.

Dewasa ini, dalam suasana global-plural, pendekatan teologi yang ekslusif tidak bisa dipertahankan lagi, karena senantiasa akan memicu persengketaan antar dan intern umat beragama. Betapa mengenaskan jika suatu kelompok umat beragama yang sebelumnya hidup rukun, lalu kemudian menjadi bersengketa disebabkan saudaranya tersinggung oleh pandangan teologisnya yang memandang orang lain sebagai orang sesat.

Sesungguhnya semua agama memang tidak sama, masing-masing agama memiliki upacara keagamaannya sendirisendiri yang menjadi tradisi sakralnya: "Bagi setiap umat Kami jadikan mansak (upacara ibadah)-nya." (Q.S. al-Hajj [22]:34 dan 68). Bentuk-bentuk upacara ibadah yang berbeda-beda itu-menurut al-Qur'an-memang merupakan sesuatu yang wajar dan alami, 
tidak bisa dihindari, dan tidak mungkin dihapus: "Sekiranya Allah menghendaki, niscaya la menjadikan kamu satu umat, tetapi la hendak menguji kamu alas anugerah-Nya kepadamu." (Q.S. al-Ma'idah [5]:48). Upacara ibadah demikian merupakan bentuk ekspresi keyakinan seseorang pemeluk suatu agama. Tinggi-rendahnya kesadaran keberagamaan seseorang biasa diukur dari ekspresi kuantitas ibadahnya. Dan seterusnya, kesadaran keberagamaan demikian senantiasa bersinergi dengan keyakinan akan kebenaran yang menjadi landasan fundamentalnya. Sesungguhnya perbedaan upacara ibadah antara satu agama dengan agama lain tidak senantiasa harus menjadi malapetaka bagi pemeluk-pemeluk agama jika hal itu disikapi secara arif atas pijakan teologis yang inklusif, lapang, dan toleran.

Bukankah al-Qur'an telah menjelaskan bahwa: "Sesungguhnya orang-orang yang beriman, orang-orang Yahudi, orang-orang Nasrani, dun orang-orang Sabea, siapa saja di antara mereka yang benar-benar beriman kepada Allah dan hari kemudian, dan beramal saleh, mereka akan menerima pahala dari Tuhan mereka, tidak ada kekhawatiran terhadap mereka, dan tidak [pula] mereka bersedih hati." (Q.S. al-Baqarah [2]:62).

Kendati masing-masing agama berbeda dengan agama lain dalam keyakinan dan upacara ritualnya, semua agama memiliki satu tujuan inti, yakni keselamatan dan kedamaian bagi manusia. Keselamatan dan kedamaian itu akan bisa terwujud ketika para pemeluk agama itu berkompetisi dala melakukan kebajikan dan menjauhkan diridarisaling menghasut, memfitnah, dan melakukan tindakan-tindakan jahat: "Seandainya Tuhanmu menghendaki, tentu Dia menjadikan manusia umat yang satu, tetapi mereka senantiasa berselisih pendapat, kecuali orang-orang yang diberi rahmat oleh Tuhanmu. Dan untuk itulah Allah menciptakan mereka." (QS. Hud [11]:118-9).

\section{Tauhid: Titik Temu Agama-Agama}

Masing-masing agama tampil dengan waj ah dan penampilan yang berbeda antara satu dan yang lain. Penampilan yang berbeda akan mencirikan distingsi antara satu agama dengan agama lain, sehingga ditemukan berbagai bentuk (form) keberagamaan dalam kehidupan manusia. Akan tetapi, penampilan yang berbedabeda antara satu agama dan agama lain, tidak menafikan adanya sesuatu yang substantif dari agama-agama itu. Di balik bentuk 
lahiriah (eksoterik) terdapat substansi keberagamaan yang paling inti, yang menjadi milik semua agama. Inilah yang disinyalir oleh firman Allah: "Dia (Allah) telah mensyariatkan bagi kamu tentang agama sebagaimana yang telah Dia pesankan kepada Nuh dan yang Kami wahyukan kepadamu serta Kami pesankan kepada Ibrahim, Musa, dan 'Isa adalah bahwa tegakkanlah olehmu agama dan janganlah kamu berpecah-belah mengenainya. Terasa berat bagi kaum musyrik apa yang engkau(Muhammad) serukan itu. "(QS. al-Syura [42]:13).

Substansi yang melandasi semua agama yang benar adalah kepercayaan bahwa ada satu Yang Mutlak, yang kepada-Nya tunduk dan patuh fisldm) segenap jagat raya. Kepercayaan demikianlah yang diisyaratkan oleh al-Qur'an sebagai ruang temu (common platform) semua agama: "Katakanlah, hai Ahli Kitab, marilah menuju kalimah sawa' (ruang temu) antara kami dan kamu bahwa kita tidak menyembah melainkan Allah dan kita tidak menyekutukan-Nya dengan sesuatu." (QS. Al 'Imran [3]:64). Siapa Allah itu? Dalam Islam Dia adalah Tuhan Yang Maha Esa, Pencipta langit dan bumi, sama seperti dalam agama Nasrani, dan Yang Maha Esa itu disebut oleh umat Yahudi dengan Yehovah, disebut oleh orang-orang Yunani kuno dengan Zeus, atau disebut oleh orang-orang India-Aria dengan Deus. Apa pun nama yang disandangkan kepada-Nya, semua umat beragama mengakui bahwa Dia tidak lain adalah Tuhan Yang Mutlak, Pencipta dan Pengatur alam semesta. Oleh sebab itu, soal nama bukan merupakan sesuatu yang fundamental, karena yang disembah oleh umat beragama bukan nama (ism, name), tetapi Yang Dinamai (al- musammd, the named). Inilah yang disinyalir oleh Ja'far al-Shadiq (w. 148 H/767 M) dalam ucapannya: "Barangsiapa yang menyembah Allah [nama dan substansi-Nya], maka dia telah musyrik. Akan tetapi, siapa yang menyembah Zat yang diacu oleh kata Allah itu, dialah yang bertauhid". ${ }^{3}$

Jika kita mempersoalkan nama, sebenamya al-Qur'an sendiri menyebut Tuhan dengan banyak nama, hanya saja namanama yang banyak itu tercakup dan terwadahi dalam nama "Allah". Hal ini bermakna bahwa soal nama adalah soal eksoterik. Di situ akan ditemukan sesuatu yang banyak, tetapi pada sisi esoterisnya,

${ }^{3}$ Abū Ja'far Muhammad, al-Tau'hìd, (Qum: Mu'assasāt al-Nasyr al-Islāmi, 1389), h. 220. 
semuanya mengacu kepada "Yang Satu". Di satu sisi, manusia tidak dapat terlepas dari masalah nama, atau bahasa pada umumnya. Karena bagaimana pun, manusia tidak bebas dari penggunaan bahasa sebagai salah satu alat komnikasinya, sehingga komunikasi dengan Tuhan pun harus dengan menggunakan bahasa.

Akan tetapi, di sisi lain, sebagai dikatakan Ibn 'Arabi, Tuhan dalam kemutlakan-Nya tidak memerlukan nama (bahasa). ${ }^{4}$ Sebab, nama ataupun bahasa pada umumnya tidak bebas dari keterbatasan. Karena itu, jika Tuhan diberi nama atau label, kata Pannikar, sama dengan menutupi rembulan dengan jari telunjuk. ${ }^{5}$ Dari itu, diam (silence), lanjut Pannikar, adalah bahasa tertinggi yang melewati bahasa ucapan dan bahasa pikiran, untuk menyapa Tuhan, agar terhindar dari sikap menduga-duga terhadap Tuhan. Sekarang kita bertemu dengan kemusykilan, di satu sisi manusia yang terbatas menghendaki medium, yang tentu saja terbatas pula,untuk mendekati Tuhan Yang Mutlak. Tetapi, di sisi lain, Tuhan, dengan kemutlakan-Nya tidak butuh mediator yang terbatas itu, karena setiap menggunakan media yang terbatas berarti membatasi kemutlakan-Nya. Dalam hal ini, kaum teolog k'asik Islam ada yang cenderung berupaya memelihara transendensi Tuhan (tanzih), seperti yang dilakukan kaum Mu'tazilah yang tidak mau melabeli Tuhan dengan "sifat-sifat". ${ }^{6}$

Di sisi lain, kaum Musyabbihah (Antropomorphis) menonjolkan imanensi-Nya (tasybih), dengan melabeli Tuhan dengan berbagai sifat seperti sifat-sifat yang ada pada makhluk. Dari itu, jika Tuhan dilihat dari perspektif kaum Mu'tazilah, maka manusia akan senantiasa merasa jauh dari Tuhan, sehingga manusia hidup dalam dunia kesepian. Akan tetapi, jika menggunakan perspektif Musyabbihah, maka Tuhan akan menjadi "setara" dengan makhluk, karena tidak ada lagi batas antara Yang Mahaagung dengan makhluk yang profan. Dari itu, kaum sufi, terutama Ibn 'ArabT, dengan menggunakan pendekatan esoteris, melihat bahwa secara substantif Tuhan tidak dapat diprediksi dengan alat, bahasa,

${ }^{4}$ Yunasril Ali, Manusia Citra Ilahi: Pengembangan Konsep Insan Kamil Ibn 'Arabi oleh al-Jili, (Jakarta: Penerbit Paramadina, 1997), h. 61-71.

${ }^{5}$ Raimundo Panikkar, Myth, Faith, and Hermeneutics, (New York: Paulist Press, 1979), h. 266.

${ }^{6}$ Ibid., 
atau simbol apapun: Laysa ka-mislihi syai' (Tidak ada sesuatu pun yang menyamai-Nya), demikian ungkapan al-Qur'an (QS. al-Syura' [42]: 11). Dia adalah Dia, di luar batas jangkauan akal manusia yang serba terbatas, di luar batas ruang dan waktu. Akan tetapi, Tuhan, dilihat dari sisi sifat dan asma-Nya, adalah imanen dengan alam, la lebih dekat dari nadi leher manusia (QS. Qaf [50]: 16). Segenap sifat dan asma-Nya imanen pada alam semesta, dan terproyeksi pada manusia. Karena itu, manusia disebut pula sebagai miniatur alam (alam shaghīr).

Pendekatan esoteris terhadap Kebenaran, niscaya akan menghilangkan sekat-sekat teologis-ekslusifis, yang menjadikan manusia terkotak-kotak dalam konsep-konsep akalnya sendiri. Dalam pandangan esoteris, Yang Maha Esa itulah Kebenaran Mutlak (The Truth), tidak terbagi, tetapi dari Yang Satu itu memancar berbagai "kebenaran" (truths) sebagaimana matahari yang secara niscaya memancarakan cahayanya. Hakikat cahaya adalah satu dan tanpa wama, tetapi spektrum kilatan cahayanya ditangkap oleh mata manusia dalam kesan yang beraneka warna. ${ }^{7}$ Jadi, secara esoteris kebenaran itu adalah tunggal, namun la ber-tajalli dalam wadah yang aneka, sehingga la "terlihat" sebagaimana corak wadah pengungkapan diri-Nya, lawn al-md' lawn ind'ihi (warna air adalah [sebagaimana] wama wadahnya), demikian ucapan Abu Yazid alBusthamt (w. sekitar 261 H/874 M)

\section{Memahami Agama Melalui Pendekatan Esoterik}

Ajaran agama dapat didekati dengan berbagai metode pendekatan, seperti pendekatan tekstual, kontekstual, hermeneutik, sejarah, fenomenologi, dan lain-lain. Pada tataran norma keagamaan, ajaran agama dapat didekati dari dimensi eksoterik dan esoteriknya. Pendekatan esoterik adalah upaya untuk melihat agama secara mendasar dengan mengkaji hakikat yang dikandung oleh ajaran agama tersebut. Kalau pendekatan eksoterik lebih banyak menyoroti dimensi formalitas ajaran agama, maka pendekatan esoterik lebih banyak menyoroti makna dan inti suatu ajaran agama. Seumpama ajaran tentang salat dalam

${ }^{7}$ Abū Nashr al-Sarrāj, Kitab al-Lumā', (ed.) R.A. Nicholson (Leiden: E.J. Brill, 1914), h. 46. 
agama Islam, pendekatan eksoterik lebih terfokus untuk melihat sah atau tidaknya pelaksanaan ibadah salat. Dalam hal ini, yang menjadi fokus perhatian adalah syarat dan rukun (elemen-elemen) yang menjadi bangunan ibadah salat secara lahir. Sehingga dengan terpenuhinya syarat dan rukun itu, maka ibadah salat disebut sempuma dan dipandang sah secara formal.

Dengan demikian, kewajiban Muslim sudah dipandang telah tertunaikan. Akan tetapi, apakah salat yang secara formal telah diselesaikan itu telah mencapai tujuan pokok perintah salat? Apakah mungkin hanya dengan memenuhi syarat-syarat dan rukun salat itu saja salat telah dapat mengantarkan seseorang terbebas dari segala bentuk perbuatan keji dan mungkar-sebagaimana diungkapkan oleh Kitab Suci? Bukankah banyak kita saksikan orang yang melakukan salat juga melakukan perbuatan tak terpuji?

Pertanyaan-pertanyaan di atas menggelitik kita untuk merenung kembali bahwa pendekatan ajaran-ajaran agama yang hanya melalui pendekatan eksoterik semata temyata tidak sepenuhnya bisa mengantarkan kita kepada inti keberagamaan. Pendekatan esoterik adalah dimensi lain dari pendekatan keberagamaan. Yang menjadi fokus pendekatan esoterik adalah menyangkut hakikat, makna, dan tujuan pokok ajaran agama, atau apa yang menjadi substansi ajaran agama. Dalam al-Qur'an Allah menerangkan bahwa diri-Nya adalah al-Zahir (Yang Lahir) dan al-Batin (Yang Batin). Oleh sebab itu, jika alam semesta yang menjadi alamat dari nama-nama dan sifat-sifat-Nya, maka alam ini pun terdiri atas lahir dan batin. Eksistensi lahiriah benda-benda alam bukan semata-mata khayalan, tetapi memiliki realitas sesuai dengan tingkatannya. Di samping itu, realitas benda-benda itu mengandung gerak menjauh dan memisah dari

Prinsip yang terletak di Pusat, yang bisa diidentikkan dengan Yang Batin. Dengan demikian, hidup lahiriah berarti memperoleh eksistensi, yang dengan itu benda-benda memiliki wujud. Akan tetapi, memfokuskan diri pada, wujud lahir semata berarti pengingkaran terhadap kodrat manusia yang sesungguhnya, karena pada yang batinlah tersimpan makna-makna dan prinsipprinsip kehidupan yang sebenamya. Oleh sebab itu, ketika kita hanya memfokuskan diri kepada yang lahir, maka tak ada yang 
kita dapatkan kecuali dunia keberagaman yang tak habis-habisnya. Sebaliknya, ketika kita masuk ke relung batin, niscaya kita akan mendapatkan inti dari dunia yang serba-ragam dalam satu hakikat. Pengetahuan esoterik membawa kita ke arah yang maknawi dan sekaligus ke Prinsip dan Pusat segala sesuatu, sehingga mencapai Pusat Yang Transenden.

Melihat ajaran agama pada dimensi eksoteriknya yang beragam berarti kita melihat eksistensi keberagamaan dalam penampilannya yang warna-warni. Bahkan, semakin jauh kita memasuki relung-relung keragaman itu, niscaya kita akan mendapatkan aneka ragam yang lebih banyak lagi, dan itulah realitas keberagamaan yang kita saksikan. Tanpa realitas demikian, keberagamaan tidak memiliki wujud sama sekali. Dan jika keberagamaan tanpa wujud, itu adalah sesuatu yang absurd. Sebaliknya, jika kita melihat dimensi esoterik, maka yang kita rasakan adalah makna keberagamaan yang demikian luas dan kaya. Memasuki relung esoterik keberagamaan berarti memasuki dunia makna yang tak bertepi, maka yang kita rasakan adalah kedamaian yang tak pemah berakhir, karena kita telah semakin dekat dengan Pusat kedamaian yang sebenamya dan tak terbatas.

Dalam Islam, pendekatan esoterik terhadap ajaran agama dilakukan terutama oleh para sufi dalam kajian tasawuf atau 'irfan. Dengan demikian, kajian dan aktivitas sufistik akan membawa kita kepada dunia makna yang lebih luas, dan dalam keluasan maknamakna itulah tersimpan kedamaian ruhani yang sesungguhnya. AlQur'an sebagai wahyu Allah yang abadi, yang kita jadikan sumber pengetahuan, memiliki dimensi eksoterik dan esoterik. Dimensi eksoteriknya ialah ajaran formalnya yang kita petik dari teksnyayang termaktub dalam Mushaf, sementara dimensi esoteriknya adalah makna-makna yang demikian luas dan kaya, yang terkandung di balik teks. Sabda Nabi saw.: "Sesungguhnya al-Qur'an memiliki lahir, batin, batas akhir, dan sumber awal." (H.R. Ibn Hibban).

Keluasan dan kekayaan dimensi esoterik al-Qur'an tak tentu ujungnya dan tak pemah mengalami kekeringan. Oleh sebab itu, 'Ali ibn Abi Thalib r.a., ketika berbicara tentang kandungan surat al-Fatihah, mengatakan, "Kalau aku man, aku akan membebankan tafsir surat al-Fatihah kepada tujuh puluh ekor unta." Dimensi

${ }^{8}$ Ucapan Ali r.a. ini dikutip oleh al-Gazali dalam karya monumentalnya 
eksoterik tafsir surat al-Fatihah mungkin hanya beberapa lembar kertas, tetapi dimensi esoteriknya memiliki makna yang demikian luas dan kaya, sehingga digambarkan bisa dibawa oleh tujuh puluh ekor unta.

Mempelajari dimensi esoterik Kitab Suci ini berarti memahami dan merasakan makna yang dikandung oleh teks untuk diterapkan dalam kehidupan, sehingga kita memperoleh kearifan dalam hidup. Dengan demikian, kedamaian yang didapatkan oleh para arif bukan hanya kedamaian statis, tetapi justru membawa semangat baru dalam kehidupan Islam. Kearifan demikianlah dalam pandangan Seyyed Hossein Nasr - yang telah memberikan semangat kepada segenap struktur Islam, baik dalam perwujudan sosial, intelektual, dan spiritual. Dalam sosial, ia mencontohkan pada persaudaraan suci dalam lembaga-lembaga tarekat dan futuwwah telah mampu memberi wama moral yang luhur bagi kehidupan masyarakat. Dalam hal intelektual, inspirasi-inspirasi segar yang tumbuh dari ruhani yang suci telah memunculkan kreasi-kreasi baru dalam bidang ilmu pengetahuan dan filsafat. Lebih-lebih lagi dalam seni, hampir setiap bentuk seni terlihatjelas perpaduannya dengan tasawuf. Para sufi pun hidup di dunia ini sekan-akan tinggal pada pelataran Taman Pirdaus, karenanya mereka menghirup udara keruhanian yang penuh kedamaian di mana keindahan memancar dari segenap perkataan dan perbuatan mereka. Islam sendiri menyebut salah satu aspek ketuhanan sebagai al-Jamal (Maha Indah) dan gambaran ini sangat ditekankan dalam tasawuf.. Sementara menyangkut kondisi spiritual merupakan kandungan utama tasawuf. Karena itu, jika disebut spiritual Islam, maka istilah demikian adalah identik dengan tasawuf, 'irfan, ataupun pengetahuan esoterik Islam ${ }^{9}$

Dari pandangan esoterikyang penuh nuansa keruhanian dan keilahian itu tidak mungkin akan lahir terorisme, penganiayaan, penjagalan, kebrutalan, dan berbagai bentuk kekerasan lainnya. Suasana keruhanian yang diliputi oleh nuansa keindahan ilahiah sulit untuk membuat orang menjadi brutal. Apalagi

Ihyā' 'Ulum al-Din, (Beirut: Dār al-Kutub al-'Ilmiyyah, t.th.), vol. I, h. 341.

${ }^{9}$ Sayyed Hossein Nasr, The Heart of Islam, terj. Indonesia oleh Nurasiah Fakih Sutan Harahap, (Bandung: Penerbit Mizan, 2003), h. 273-82. 
dalam tasawuf yang nota bene merupakan inti esoterisme Islam sangat menekankan pengendalian hawa-nafsu dan membuang jauh-jauh tabiat jelek, maka di sini tidak akan muncul tabiattabiat kekerasan dan kebengisan. Ketika suasana yang jauh dari kekerasan ditonjolkan, maka yang akan muncul adalah kedamaian dan kesyahduan. Suasana demikianlah yang menjadi misi utama segenap agama langit.

Dengan demikian, mempelajari agama hanya melalui satu pendekatan merupakan kemiskinan. Kemiskinan demikian membuat orang hanyut untuk memperturutkan hawa-nafsunya sendiri. Mungkin ia merasa apa yang ia lakukan itu sebagai sesuatu yang bersumber dari Tuhan, karena keterbatasannya memahami pesan-pesan-Nya, sehingga ia tergelincir memperturutkan hawanafsunya sendiri. Keadaan demikianlah yang membuat orang merasa sempit dalam beragama, dan kepicikan itulah yang menjadi sumber ketidaknyamanan dalam keberagamaan.

\section{E. Penutup}

Memahami ajaran agama dari sisi pandang esoterik bermakna melihat hakikat yang sesungguhnya ajaran agama, di luar batas sekat- sekat legal-formal. Pandangan ini lebih jauh akan membuka tabir kebenaran yang dikandung oleh agamaagama samawi, yang diturunkan Tuhan sejak Adam a.s sampai Muhammad saw. Meskipun para nabi dan rasul telah bergantian datang, kebenaran yang mereka bawa adalah satu, yang bersumber dari Allah, Tuhan Yang Maha Esa itulah inti sesungguhnya ajaran agama-agama; sementara perbedaan dan distinksi hanya terletak pada bentuk lahir, dan ini sesuai dengan kondisi dan kebutuhan umat di watu mana nabi atau rasul itu diutus.

Pandangan esoterik demikian akan menjauhkan umat dari rasa fanatik berlebihan terhadap agama yang dipeluknya, yang berdampak pada rasa sempit dan picik dalam menatap masa depan. Lalu, lebih jauh, pandangan ini akan mendekatkan umat satu agama dengan umat agama lain, sehingga akan didapatkan suatu ruang temu agama- agama. Dalam ruang temu itu akan tumbuh dialog antar umat beragama dalam melihat masa depan manusia secara keseluruhan. 
Dalam susana bersahabat demikianlah, agaknya, Allah swt. menurunkan rahmat-Nya, sehingga manusia akan diliputi oleh rasa damai dan tenteram. Sebaliknya, selama masih ada rasa benci dan permusuhan antar sesama manusia, selama itu pula kita akan terhimpit oleh rasa resah, sesak dada, taku.t, dan berbagai perasaan yang mengusik kedamaian.

Sesungguhnya agama kita tidak perlu sama, karena memang demikian kehendak Ilahi, tetapi antara satu umat penganut suatu agama dan umat agama yang lain perlu saling memahami, menghormati, dan mencintai. Untuk menuju ke arah itu diperlukan pemahaman agama yang komprehensif, tidak tertabiri oleh sekatsekat legal-formal, saiah satunya adalah melalui pendekatan dan pemahaman esoterik. [.]

\section{Daftar Pustaka}

Ali, Yunasril, Manusia Citra Ilahi: Pengembangan Konsep Insan Kamil Ibn 'Arabi oleh al-jili, Jakarta: Penerbit Paramadina,1997

al-Gazali, Ihyā' 'Ulūm al-Dān, Beirut: Dār al-Kutub al-'Ilmiyyah, t.th., vol. 1.

Muhammad, Abū Ja'fār, al-Tauhỉd, Qum: Mu'assasāt al-Nasyr alIslam, 1389.

Muthahhari, Murtadha, Perspektif al-Qur'an tentang Manusia dan Agama, terj. Indonesia oleh Tim Penerjemah Mizan, Bandung: Penerbit Mizan, 1419/1998.

Nasr, Sayyed Hossein, The Heart of Islam, terj. Indonesia oleh Nurasiah Fakih Sutan Harahap, Bandung: Penerbit Mizan, 2003

Nasr, Seyyed Hossein, The One in the Many, dipresentasikan pada Parliament of the Word's Religions, Chicago, 2 September 1993.

Panikkar, Raimundo, Myth, Faith, and Hermeneutics New York: Paulist Press, 1979

Al-Sarraj, Abū Nashr, Kitāb al-Lumā', (ed.) R.A. Nicholson, Leiden: E.J. Brill, 1914. 
M. Ikbal 